\title{
Chemical Composition of Gas and Particle Phase Products of Toluene Photooxidation Reaction under High $\mathrm{OH}$ Exposure Condition
}

\author{
Yik-Sze Lau ${ }^{1}$, Man-Nin Chan ${ }^{2}$, Hon-Yin Poon ${ }^{1,2}$, Yan Tan ${ }^{3} \mathbb{D}$, Shun-Cheng Lee ${ }^{3} \mathbb{D}$, Jianjun Li ${ }^{4}$ (D) \\ and Kin-Fai Ho ${ }^{1,2, *}$
}

check for

updates

Citation: Lau, Y.-S.; Chan, M.-N.;

Poon, H.-Y.; Tan, Y.; Lee, S.-C.; Li, J.;

Ho, K.-F. Chemical Composition of

Gas and Particle Phase Products of Toluene Photooxidation Reaction under High $\mathrm{OH}$ Exposure Condition. Atmosphere 2021, 12, 915. https:// doi.org/10.3390/atmos12070915

Academic Editor: Daniele Contini

Received: 2 June 2021

Accepted: 9 July 2021

Published: 15 July 2021

Publisher's Note: MDPI stays neutral with regard to jurisdictional claims in published maps and institutional affiliations.

Copyright: (c) 2021 by the authors. Licensee MDPI, Basel, Switzerland. This article is an open access article distributed under the terms and conditions of the Creative Commons Attribution (CC BY) license (https:// creativecommons.org/licenses/by/ $4.0 /)$.
1 JC School of Public Health and Primary Care, The Chinese University of Hong Kong, Hong Kong, China; yiksze.lau@hdr.qut.edu.au (Y.-S.L.); $1155064047 @ l i n k . c u h k . e d u . h k$ (H.-Y.P.)

2 Earth System Science Programme, The Chinese University of Hong Kong, Hong Kong, China; mnchan@cuhk.edu.hk

3 Department of Civil and Structural Engineering, The Hong Kong Polytechnic University, Hong Kong, China; yan.tan@connect.polyu.hk (Y.T.); shun-cheng.lee@polyu.edu.hk (S.-C.L.)

4 State Key Laboratory of Loess and Quaternary Geology, Institute of Earth Environment, Chinese Academy of Sciences, Xi'an 710061, China; lijj@ieecas.cn

* Correspondence: kfho@cuhk.edu.hk

\begin{abstract}
In the current study, the photooxidation reaction of toluene $\left(\mathrm{C}_{7} \mathrm{H}_{8}\right)$ was investigated in a Potential Aerosol Mass Oxidation Flow Reactor (PAM OFR). The hydroxyl radical (OH) exposure of toluene in the PAM OFR ranged from 0.4 to $1.4 \times 10^{12} \mathrm{molec} \mathrm{cm}^{-3} \mathrm{~s}$, which is equivalent to 3 to 12 days of atmospheric oxidation. A proton transfer reaction-mass spectrometer (PTR-MS) and a scanning mobility particle sizer (SMPS) were used to study the gas-phase products formed and particle number changes of the oxidation reaction in PAM OFR. The secondary organic aerosol (SOA) formed in the PAM OFR was also collected for off-line chemical analysis. Key gas-phase reaction products of toluene, including glyoxal, methyl glyoxal, unsaturated carbonyl compounds, and benzaldehyde, were identified by the PTR-MS. Second generation products, including acetic acid, formaldehyde, formic acid, and acetaldehyde, were also detected. By comparing the mass spectrums obtained under different $\mathrm{OH}$ exposures and relative humidity $(\mathrm{RH})$, changes in the two parameters have minimal effects on the composition of gas-phase products formed, expect for the spectrum obtained at $\mathrm{OH}$ exposure of $0.4 \times 10^{12} \mathrm{~cm}^{-3} \mathrm{~s}$ and $\mathrm{RH}=17 \%$, which is slightly different from other spectrums. SMPS results showed that particle mass concentration increases with increasing $\mathrm{OH}$ exposure, while particle number concentration first increases and then decreases with increasing $\mathrm{OH}$ exposure. This result probably suggests the formation of oligomers at high $\mathrm{OH}$ exposure conditions. Off-line chemical analysis of the SOA sample was dominated by C4 diacids, including malic acid, citramalic acid, and tartaric acid. The well-known toluene SOA marker 2,3-Dihydroxy-4oxopentanoic acid, as well as 2,3-dihydroxyglutaric acid, which has not been identified in previous toluene photooxidation experiments, were also detected in the SOA sample. Our results showed good agreements with the results of previous smog chamber studies of toluene photooxidation reaction, and they suggested that using PAM OFR for studies of oxidation reaction of different VOCs can be atmospherically relevant.
\end{abstract}

Keywords: Potential Aerosol Mass (PAM); toluene; PTR-MS; photooxidation; ageing

\section{Introduction}

Formation of secondary organic aerosol (SOA) in the atmosphere has become the emerging topic in atmospheric science and chemistry in the recent decades. It has been shown in previous studies that SOA is associated with air pollution and haze events [1], which affects the global climate forcing by serving as a cloud condensation nuclei and participating in heterogeneous chemical reactions [2,3]. It has also been shown that exposure 
to SOA is associated with different adverse effects on human health [4]. SOA makes up a large fraction of the submicron-sized atmospheric organic aerosol (OA) [5], and these OA can trigger respiratory and cardiovascular diseases [6,7]. Therefore, understanding the formation mechanism of SOA is crucial to both the study of atmospheric processes and public health. A myriad of studies have attempted to reveal the physical and chemical reactions leading to the formation of SOA from their precursor species [8-10]. In spite of the number of studies, the understanding of the formation processes of SOA in the atmospheric is still far from complete. For example, model predictions based on the experimental yield of SOA generally underestimate the mass loading of SOA in ambient measurements [11,12]. The discrepancy between empirical and observed value mainly arise from the uncertain emission inventory of low volatility SOA precursors $[13,14]$, and the heterogenous and ageing reactions involved in SOA formation [15]. Therefore, it can be foreseen that study of SOA formation mechanism will continue to play an important role in atmospheric studies in the coming decades.

There are many challenges in the study of SOA formation from their VOC precursors. For example, the abilities of the experimental setup to simulate atmospheric conditions, and the time scale of the reactions. In the last few decades, SOA experiments were almost exclusively conducted in smog chambers. The advantage of using smog chamber to simulate atmospheric oxidation reaction of VOCs leading to the formation of SOA is that it can reasonably simulate the conditions in the atmosphere, i.e., being atmospherically relevant. However, there are limitations of smog chamber experiments. For example, loss of particles to the chamber wall hindered the ability of using smog chamber to study reactions with time scales up to several days or weeks [16]. In the recent years, the use of oxidation flow reactor (OFR) to study atmospheric processes has become more and more popular. In particular, Potential Aerosol Mass (PAM) OFR, which is the only commercialized OFR on market, has been used by many research groups for their studies. The concept of PAM was first introduced by Kang et al. [17], which utilizes extreme amounts of oxidant (predominantly hydroxyl radical $\mathrm{OH}$ ) to simulate photochemical ageing processes in the atmosphere. The advantages of PAM included short experimental time, low wall loss, the ability to simulate oxidation processes with long lifetimes, and ability to deploy for field study. A comparison of key functionalities between smog chamber and OFR was given in Table 1. With the advantages of the PAM OFR, it becomes possible and easier than before to assess the effect of photochemical ageing on primary organic aerosol and VOCs, as well as some complex sources, such as vehicle emissions [18,19].

Table 1. Comparison of features between smog chamber and OFR [16].

\begin{tabular}{|c|c|c|}
\hline & Smog Chamber & OFR \\
\hline Experimental timescale & Hours to day & Minutes to hours \\
\hline Wall lose & Significant & Minimal \\
\hline OH exposure & Hours to days & Days to weeks \\
\hline Field work & Possible but not easy & Possible \\
\hline Atmospheric relevance of oxidant and precursor concentrations & Yes & Possible for precursor, impossible for oxidant \\
\hline Time for condensation and partitioning of products & Enough & Moderate \\
\hline
\end{tabular}

With the aforementioned advantages, more and more studies used OFR rather than smog chamber as their tool to investigate the atmospheric oxidation reactions. For example, Lambe et al. [20] assessed the chemical composition of SOA formed from fourteen different biogenic and anthropogenic precursors, Molteni et al. [21] studied the formation of highly oxygenated compound from aromatic VOC precursors, Palm et al. [22] deployed their PAM OFR on field to study the SOA formation of ambient forest air, and Ma et al. [23] investigated the role of $\mathrm{NO}_{\mathrm{x}}$ in the formation of sulphate, nitrate, and ammonium ion in air by PAM OFR. In spite of the extensive application of PAM OFR to study atmospheric reaction, concerns remained on its ability to truly simulate the conditions in atmosphere, i.e., if the results from PAM OFR are atmospherically relevant. Lambe et al. [24] compared the chemical compositions of SOA generated by a smog chamber and PAM OFR using 
similar $\mathrm{OH}$ exposure. Their study concluded that the AMS mass spectrums for the SOA generated by the two reactors were similar, which suggested that the SOA generated by PAM OFR is actually atmospherically relevant. In a recent review article, Peng and Jimenez [16] outlined the detailed chemistry that happens in a PAM OFR, and summarized the experimental conditions and requirements that make the chemical reactions in PAM OFR atmospherically relevant. Therefore, with extra attention and careful experimental designs, PAM OFR can be used as an alternative tool in studying atmospheric chemistry.

Although there are several previous investigations of the chemical compositions of SOA formed in PAM OFR $[21,25,26]$, most of these studies focused on the analysis of the elemental composition (e.g., $\mathrm{O} / \mathrm{C}$ ratio and $\mathrm{f}_{44}$ value) of the SOA. Direct speciation of the SOA generated by PAM OFR using well established offline analytical methods (e.g., GC or LC/MS) was limited [27]. The current study aimed at investigating the gas phase products and SOA compositions of toluene photooxidation reaction in PAM OFR. Although the photooxidation reaction of toluene is well studied in smog chambers, investigations of its aged products are scarce. Toluene is an important anthropogenic VOC commonly found in combustion processes, and therefore understanding its oxidation and ageing mechanism is crucial in predicting the SOA loading in urban environments. Since PAM OFR can generate high concentration of $\mathrm{OH}$ radicals, it can be used to investigate the atmospheric ageing process of toluene in this study. The gas phase products formed in PAM OFR was monitored by a proton transfer reaction-mass spectrometer (PTR-MS) and SOA samples were collected for offline chemical characterization. The results obtained were used to examine the relationship between the gas phase and particle phase products observed. Moreover, the changes in gas phase product composition under different experimental conditions, such as $\mathrm{OH}$ exposure and relative humidity $(\mathrm{RH})$, were assessed. The overall result of this study enhances our understanding of the photochemical ageing process of toluene and to assess the ability of PAM OFR to study atmospheric processes by comparing the results with related chamber studies.

\section{Methodology}

\subsection{PAM OFR}

The PAM OFR used in the current study is a Penn State PAM, which is developed by the Pennsylvania State University. The reactor is $45.7 \mathrm{~cm}$ long, with an inner diameter of $19.7 \mathrm{~cm}$, resulting in a volume of around $13 \mathrm{~L}$. A UV lamp (BHK Inc., Ontario, CA, USA) is mounted inside the reactor, providing UV radiation at $254 \mathrm{~nm}$ only. PAM OFR of this type is usually termed OFR254 to differentiate from its counterpart OFR185, of which the UV lamp inside the reactor produce radiation at both $185 \mathrm{~nm}$ and $254 \mathrm{~nm}$. Detailed principals and characterization of the PAM OFR in the current study can be found elsewhere $[17,28]$. Briefly, the main oxidant in PAM, OH radical, is generated inside the reactor by the reaction between water vapor and excited oxygen $\left.\left[\mathrm{O}^{1} \mathrm{D}\right)\right]$ atom. The excited oxygen $\left[\mathrm{O}\left({ }^{1} \mathrm{D}\right)\right]$ atom is produced as a result of the irradiation of $\mathrm{O}_{3}$ by UV light at $254 \mathrm{~nm}$ inside the reactor. $\mathrm{O}_{3}$ is externally generated, and injected to the reactor in prior to the injection of VOC.

\subsection{Experimental Setup}

A schematic diagram of the experimental setup is given in Figure $1 . \mathrm{N}_{2}$ and $\mathrm{O}_{2}$ were injected to the PAM OFR at a ratio of 4:1 to mimic the composition of air. $\mathrm{O}_{3}$ is generated by passing through a stream of $\mathrm{O}_{2}$ through an ozone generator (1000BT-12, ENALY, Japan). The ozone concentration was measured by an ozone monitor (Model 202, 2B Technologies, Boulder, CO, USA). RH in the PAM is controlled by the amount of $\mathrm{N}_{2}$ and $\mathrm{O}_{2}$ passing through a water bubbler. The $\mathrm{RH}$ and temperature of the outflow of the PAM OFR were monitored by a temperature/humidity sensor (HMP 110, Vaisala Inc, Finland). Toluene used in the current study is prepared in gas phase (Scientific Gas Engineering Co., Ltd., Hong Kong, China), and is directly injected to the PAM OFR. In experiments using seed particle, ammonium sulphate ( $\geq 99 \%$, Missouri Sigma-Aldrich, Inc., St. Louis, $\mathrm{MO}, \mathrm{USA})$ powder was dissolved in milli-Q water $(18.2 \mathrm{M} \Omega-\mathrm{cm})$ and then atomized by an 
atomizer (3076, TSI, Shoreview, MN, USA). The atomized $\left(\mathrm{NH}_{4}\right)_{2} \mathrm{SO}_{4}$ stream was directed through a diffusion dryer before entering the PAM OFR. The flow of all the aforementioned gases were controlled by a mass flow controller (MFC) system consisting of 8 mass flow controllers (G-series, MKS instruments, Andover, MA, USA) of different range of flow rate. The total flow of gases in the PAM OFR was maintained at $8 \mathrm{~L} \mathrm{~min}^{-1}$ for all experiments. The experiment list with all experimental conditions were given in Supporting Information. Briefly, three sets of experiments with different RH were carried out without using seed particles. For each set of $\mathrm{RH}$, different $\mathrm{OH}$ exposure was achieved by varying the amount of $\mathrm{O}_{3}$ generated externally. In addition to the aforementioned three sets of experiments, two sets of experiments with different $\mathrm{RH}$ were also carried out using $\left(\mathrm{NH}_{4}\right)_{2} \mathrm{SO}_{4}$ seed particle in order to find out the effect of seed particle on the composition of gas phase products.

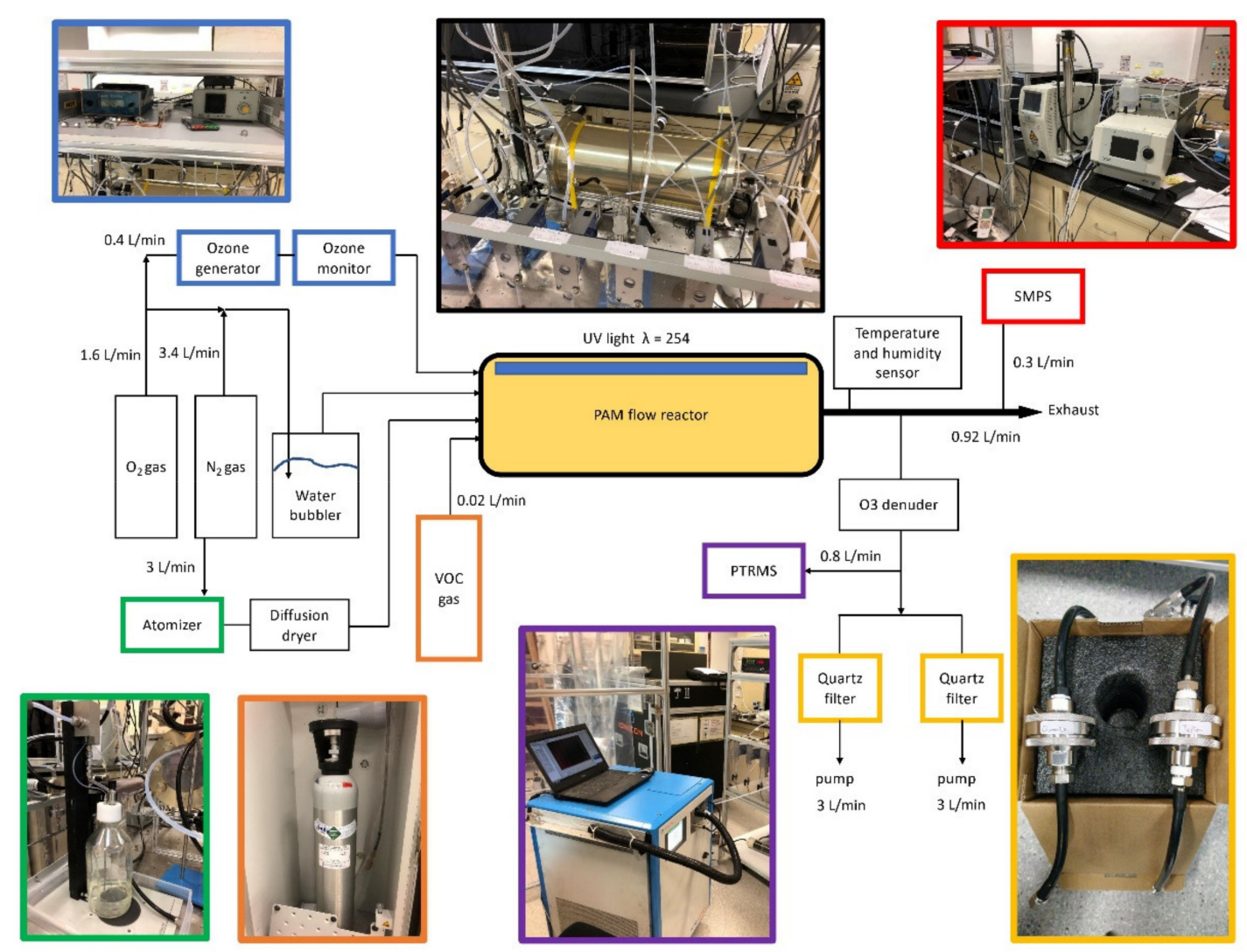

Figure 1. Schematic diagram of the instrumental setup.

To study the gas phase products generated in PAM OFR, a proton transfer reactionmass spectrometer (PTR-QMS 300, IONICON ANALYTIK GES.M.B.H., Innsbruck, Austria) was connected to the outlet of the reactor. The PTR-MS was run in scan mode to record all peaks from 21 to $250 \mathrm{~m} / z$ with resolution of $1 \mathrm{amu}$. To check if the PTR-MS was capturing the right $m / z$, the presence of peaks at $m / z=30\left(\mathrm{NO}^{+}\right.$ion) and $m / z=93$ (toluene ion) were checked before and after the injection of toluene respectively. Particle number and mass concentration at the outlet of the PAM OFR was monitored by a scanning mobility particle sizer (SMPS, TSI, Shoreview, MN, USA). One set of SOA sample was collected for off-line GC/MS analysis. These samples were collected on five quartz filters ( $47 \mathrm{~mm}$, Global Life Sciences Solutions USA LLC, Marlborough, MA, Whatman, USA) under the same experimental conditions (OH exposure $=1.4 \times 10^{12}$ molec $\mathrm{cm}^{-3} \mathrm{~s}$ and in the presence of $\left(\mathrm{NH}_{4}\right)_{2} \mathrm{SO}_{4}$ seed). The sample collection time for each filter was around $6 \mathrm{~h}$, and an average of $1.6 \mathrm{mg}$ of SOA sample was collected on each filter. An ozone denuder was installed before the filter to prevent prolonged oxidation of SOA sample on the filter by 
$\mathrm{O}_{3}$. During the study of gas phase products, blank quartz filters were put in the two filter holders to protect the pump from being stuck by the SOA generated in PAM OFR.

\subsection{Calibration of $\mathrm{OH}$ Concentration in PAM OFR}

Since direct measurement of $\mathrm{OH}$ concentration is not available in the current study, indirect determination and calibration of $\mathrm{OH}$ concentration is needed. The calibration of $\mathrm{OH}$ concentration was carried out by the method described in Lambe et al. [24], using $\mathrm{SO}_{2}$ gas. Briefly, the flow rate of PAM was set to $8 \mathrm{~L} / \mathrm{min}$, resulting in a residence time of approximately $100 \mathrm{~s} . \mathrm{SO}_{2}$ gas was delivered to the PAM together with $\mathrm{O}_{3}$ gas. Since the reaction between $\mathrm{SO}_{2}$ and $\mathrm{O}_{3}$ was insignificant compare to that between $\mathrm{SO}_{2}$ and $\mathrm{OH}$ [29], any decrease in $\mathrm{SO}_{2}$ concentration was assumed to be caused by the reaction with the $\mathrm{OH}$ radical. By measuring the $\mathrm{SO}_{2}$ at different $\mathrm{O}_{3}$ level, the $\mathrm{OH}$ concentration could be estimated by the decay of $\mathrm{SO}_{2}$ concentration via the following equation.

$$
\mathrm{OH}_{\mathrm{exp}}=-\frac{1}{\mathrm{k}_{\mathrm{SO} 2+\mathrm{OH}}} \ln \frac{\left[\mathrm{SO}_{2}\right]_{\mathrm{i}}}{\left[\mathrm{SO}_{2}\right]_{\mathrm{f}}}
$$

where $\mathrm{k}_{\mathrm{SO} 2+\mathrm{OH}}=9 \times 10^{-13} \mathrm{~cm}^{3}$ molec ${ }^{-1} \mathrm{~s}^{-1}$ at $298 \mathrm{~K},\left[\mathrm{SO}_{2}\right]_{\mathrm{i}}=\mathrm{SO}_{2}$ concentration when $\mathrm{O}_{3}$ concentration is zero, and $\left[\mathrm{SO}_{2}\right]_{\mathrm{f}}=\mathrm{SO}_{2}$ concentration at a certain $\mathrm{O}_{3}$ level. Since this calibration of $\mathrm{OH}$ concentration is $\mathrm{RH}$ sensitive $(\mathrm{OH}$ is produced by the reaction between $\left[\mathrm{O}\left({ }^{1} \mathrm{D}\right)\right]$ and water vapor), calibrations were carried out at four RH levels close to the RH used in our experiments. OH exposure calibrated span from 0.4 to $1.5 \times 10^{12}$ molec cm $^{-3} \mathrm{~s}$, which is equivalent to 3 to 12 days of atmospheric oxidation assuming the $\mathrm{OH}$ concentration in the atmosphere to be $1.5 \times 10^{6}$ molec $\mathrm{cm}^{-3}$ [30]. The calibration curves were given in Supporting Information Figure S1. After the calibration, OH exposure inside the PAM OFR could be controlled by the amount of $\mathrm{O}_{3}$ injected.

\subsection{GC/EI-MS Analysis}

The filter samples for SOA characterization were analyzed by a Gas Chromatography/Electron Ionization-Mass Spectrometry (GC/EI-MS) system. One-fourth of the quartz filter sample was cut and extracted with dichloromethane and methanol $(2: 1, v / v)$ under ultrasonication. The extracts were concentrated using a rotary evaporator under vacuum conditions and then dried by pure nitrogen gas. The dried extract was reacted with N,O-bis-(trimethylsilyl) trifluoroacetamide (BSTFA) at $70{ }^{\circ} \mathrm{C}$ for 3 hours, and the resulting derivatives were determined using gas chromatography/electron ionization mass spectrometry (GC/EI-MS).

The GC/EI-MS analysis was performed by an Agilent 7890A GC coupled with an Agilent 5975C MSD. The GC separation was carried out on a DB-5MS fused silica capillary column with the GC oven temperature programmed from $50{ }^{\circ} \mathrm{C}(2 \mathrm{~min})$ to $120{ }^{\circ} \mathrm{C}$ at $15^{\circ} \mathrm{C} \mathrm{min}^{-1}$ and then to $300{ }^{\circ} \mathrm{C}$ at $5^{\circ} \mathrm{C} \mathrm{min}^{-1}$ with a final isothermal hold at $300{ }^{\circ} \mathrm{C}$ for $16 \mathrm{~min}$. The sample was injected in a splitless mode at an injector temperature of $280^{\circ} \mathrm{C}$, and scanned from 50 to 650 Daltons using electron impact (EI) mode at $70 \mathrm{eV}$.

GC/MS response factors of 2,3-dihydroxy-4-oxopentanoic acid, malic acid, and tataric acid were determined using authentic standards. Response factors of citramalic acid and 2,3-dihydroxy-glutraric acid were substituted by those of succinic acid and tartaric acid, respectively, because the authentic standards are not commercially available. No significant contamination ( $<5 \%$ of those in the samples) was found in the blanks. Recoveries of the organic compounds represented by n-alkanes and PAHs were ranged from $80 \%$ to $120 \%$. Data presented were corrected for the field blanks but not corrected for the recoveries.

\section{Result and Discussion}

\subsection{Gas Phase Product Identification by PTR-MS}

\subsubsection{Peak Identification}

Figure 2 depicted the PTR-MS spectrum for the gas phase products observed in the three sets of experiments without seed particle. These spectrums were obtained by 
subtracting the spectrum at a certain $\mathrm{OH}$ exposure by the spectrum at $\mathrm{OH}$ exposure $=0$ molec $\mathrm{cm}^{-3} \mathrm{~s}$. Therefore, the spectrums shown in Figure 2 correspond to the products formed in the PAM OFR. Signals that were captured in all three spectrums in Figure 2 are $m / z=31,43,45,47,59,61,73,99$, and 107. By comparing the results with previous studies [31-34], the National Institute of Standards and Technology (NIST) database, and the Master Chemical Mechanism (MCM) version 3.3.1 database, the aforementioned peaks were assigned as formaldehyde $(m / z=31)$, acetyl radical $(m / z=43)$, acetaldehyde $(m / z=45)$, formic acid $(m / z=47)$, glyoxal $(m / z=59)$, acetic acid $(m / z=61)$, methyl glyoxal $(m / z=73)$, unsaturated carbonyls $(m / z=99)$, and benzaldehyde $(m / z=107)$. The proposed mechanism for the formation of these products were outlined in Figure 3. Benzaldehyde was produced through the abstraction of a methyl group hydrogen in toluene (route 2 in Figure 3), while other products were formed through the hydrogen abstraction from the benzene ring, resulting in the formation of a bicyclic peroxy radical. The bicyclic peroxy radical then decomposed to form two groups of first-generation products. The first group of products are glyoxal and unsaturated carbonyls with a molecular weight 98 , and the second group of products are methyl glyoxal and unsaturated carbonyls with a molecular weight of 84 . Further oxidation of the aforementioned first-generation products results in the production of acetaldehyde, formaldehyde, formic acid, and acetic acid. In the current study, the signal of $m / z=99$ was very weak while signal of $m / z=85$ was under detection limit. It has been shown in a previous study by Arey et al. [35] that the yields of unsaturated carbonyls were significantly lower than their smaller 1,2-dicarbonyl counterparts, which agree with the results of the current study. The weak signal of $m / z=99$ and the absence of $m / z=85$ signal showed that these unsaturated carbonyls may undergo rapid oxidation right after their formation in the PAM OFR. A rapid degradation of unsaturated carbonyls is also supported by the observation that spectrums depicted in Figure 2 were dominated by second generation products, which are the oxidation products of the unsaturated carbonyls.

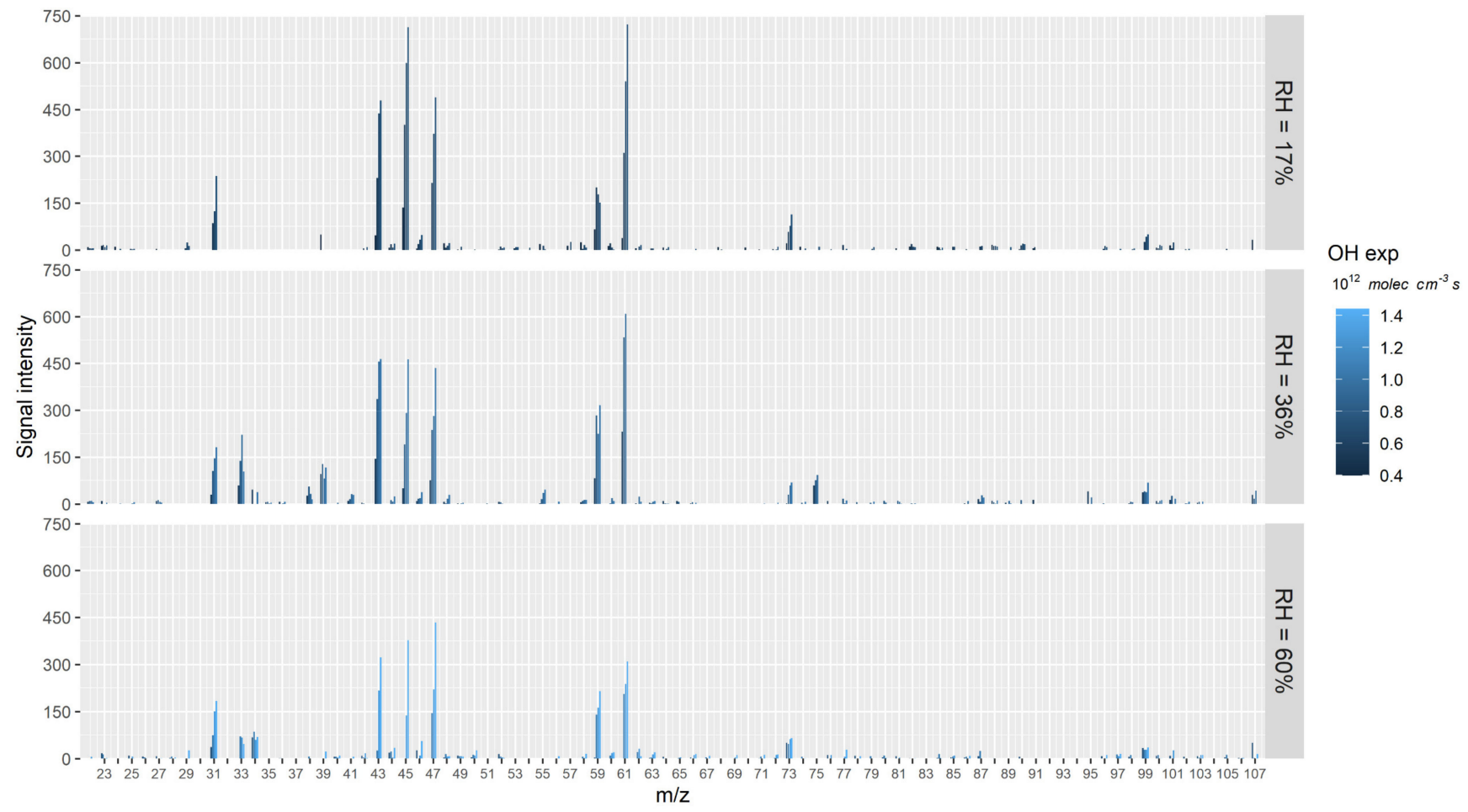

Figure 2. Mass spectrum of gas phase products observed in experiments without seed particles. All the spectrums shown are background $(\mathrm{OH}$ exposure $=0)$ corrected. 

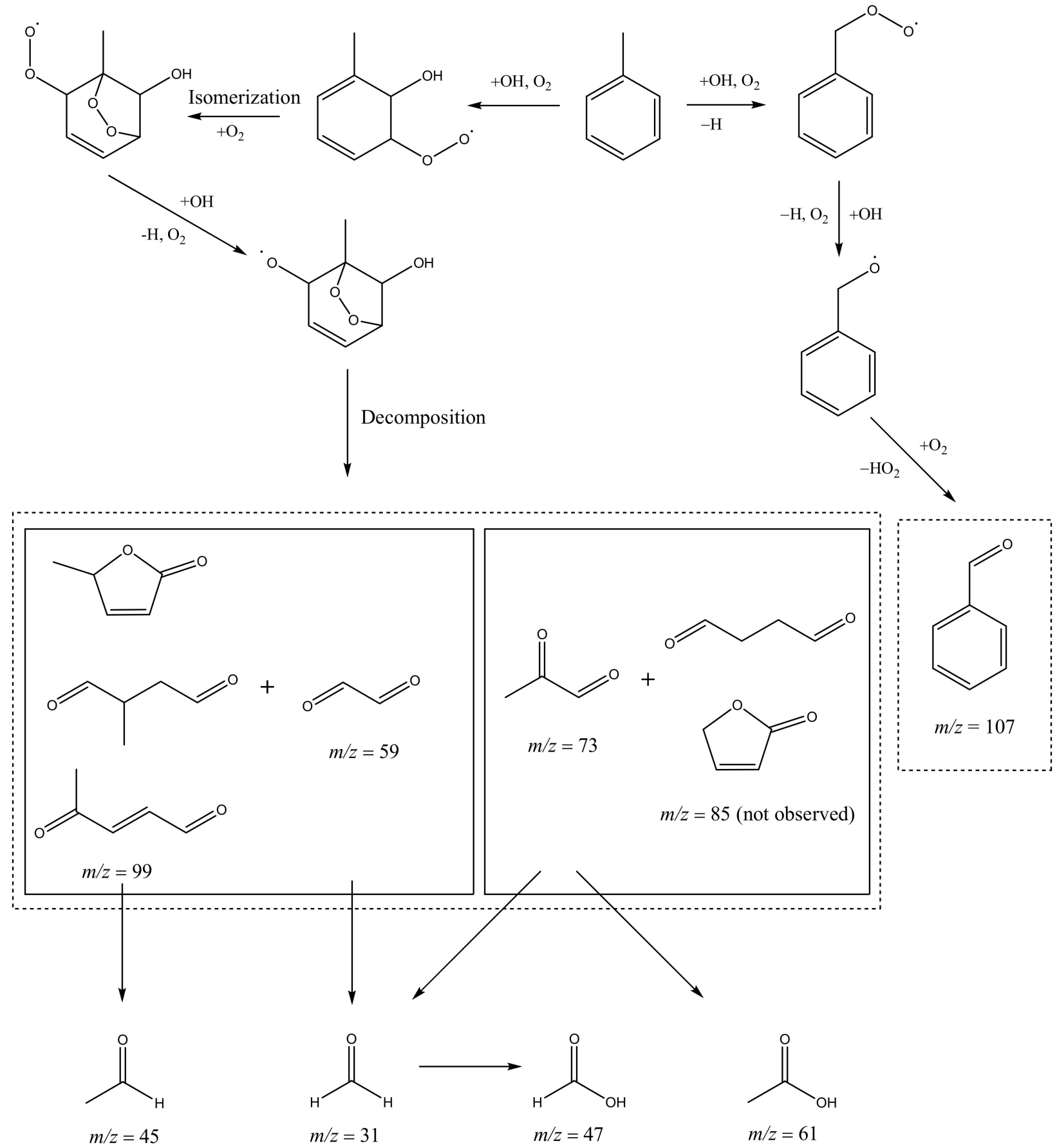

Figure 3. Proposed mechanism of toluene oxidation reaction leading to the products observed in the current study.

\subsubsection{Effect of $\mathrm{OH}$ Exposure on the Composition and Yield of Gas Phase Products}

The effect of oh exposure on the composition of the gas phase products can also be examined in Figure 2. The blue scale of the color legend represents the $\mathrm{OH}$ exposure at which the peak was identified. The lighter the color, the higher the $\mathrm{OH}$ exposure. In general, most products observed at low $\mathrm{OH}$ exposure $\left(0.4-0.8 \times 10^{12}\right.$ molec cm$\left.^{-3} \mathrm{~s}\right)$ were also observed at high $\mathrm{OH}$ exposure $\left(1.2 \times 10^{12}\right.$ molec $\mathrm{cm}^{-3} \mathrm{~s}$ or above $)$ conditions. One exceptional case was found at $m / z=107$ in Figure 2. This peak represents benzaldehyde, and its signal presents at low $\mathrm{OH}$ exposure but not at high $\mathrm{OH}$ exposure condition. The reason for the aforementioned observation can be explained by the formation and reaction mechanism of benzaldehyde in toluene oxidation reaction. As elucidated in the previous section, benzaldehyde is formed as a result of the abstraction of methyl group hydrogen 
followed by reaction with peroxy and $\mathrm{OH}$ radicals (route 2 in Figure 3). At high $\mathrm{OH}$ exposure conditions, benzaldehyde further oxidized to low volatility products (e.g., benzoic acid), which was not detected by PTR-MS. Therefore, benzaldehyde was observed in low $\mathrm{OH}$ exposure conditions, while its signal disappeared at high $\mathrm{OH}$ exposure conditions.

To quantify the similarities between gas phase products formed under different experimental conditions, the dot products between the mass spectrums obtained in different conditions were calculated. The dot product approach has been used to quantify the similarities between mass spectrums in previous studies $[24,36]$. To calculate the dot product of a spectrum, the intensity of a peak is divided by the square root of the sum of the squares of the intensity of all peaks in the spectrum. The result of this normalization process is represented by a vector $A$, where $A=\left[a_{1}, a_{2}, a_{3}, \ldots\right]$, and $a_{1}, a_{2}, a_{3}, \ldots$ represent the normalized intensity of peaks at each $m / z$ in the spectrum. When two vectors, A and $B$, were obtained by the aforementioned normalization method from two different mass spectrums, the dot product of $\mathrm{A}$ and $\mathrm{B}$, denoted by $\mathrm{A} \cdot \mathrm{B}=\sum_{i=1}^{n} a_{i} b_{i}$, can be used to quantify the similarities between the two spectrums. When $\mathrm{A} \cdot \mathrm{B}=0$, the two spectrums are orthogonal. When $\mathrm{A} \cdot \mathrm{B}=1$, the two spectrums are identical.

The results of dot products calculated between different $\mathrm{OH}$ exposure and $\mathrm{RH}$ were depicted as a correlogram in Figure 4. In general, most of the dot products between spectrums obtained under same $\mathrm{RH}$ but different $\mathrm{OH}$ exposures are very close to 1 , as shown by the deep blue color boxes. One exceptional case was observed at $\mathrm{RH}=17 \%$ with $\mathrm{OH}$ exposure of $0.40 \times 10^{12}$ molec $\mathrm{cm}^{-3} \mathrm{~s}$, which is the lowest $\mathrm{OH}$ exposure in the current study. The spectrum under this condition showed a decrease in dot product with increasing $\mathrm{OH}$ exposure, as depicted by the gradual change of color from deep blue to deep yellow. The above observations suggest that except for the lowest $\mathrm{OH}$ exposure in this study $\left(\mathrm{OH}\right.$ exposure $=0.40 \times 10^{12} \mathrm{~cm}^{-3} \mathrm{~s}$ ), the $\mathrm{OH}$ exposure range investigated by our experiments is high enough to reach the "final stage" of gas-phase oxidation, and further increase in $\mathrm{OH}$ exposure will not change the gas-phase product compositions significantly. At $\mathrm{OH}$ exposure $=0.40 \times 10^{12} \mathrm{~cm}^{-3} \mathrm{~s}$, the oxidation reaction of toluene does not reach the "final stage", and therefore its gas-phase product composition is different from other experimental conditions in the current study.

Although $\mathrm{OH}$ exposures in the current study have minimal effects on the composition of gas-phase products, they significantly affect the yield of the gas-phase products observed. Figure 5 visualized the effect of $\mathrm{OH}$ exposure on the major gas phase products observed in the Figure 2. In general, an increase in $\mathrm{OH}$ exposure will increase the yield of the gas phase products observed, except for benzaldehyde. Figure 5 divided the products into two groups, namely the first generation products and second generation products. It can be observed that for second generation products, an increase of $\mathrm{OH}$ exposure causes a smooth increase of the signal of the products, while for first generation products, a more complicated trend was shown. The main reason for this observation is that first generation products serve as the product of toluene photooxidation as well as the percussors of the second generation products, and therefore when its production rate is lower than the consumption rate, a decrease on the signal of the first generation products will be observed. 


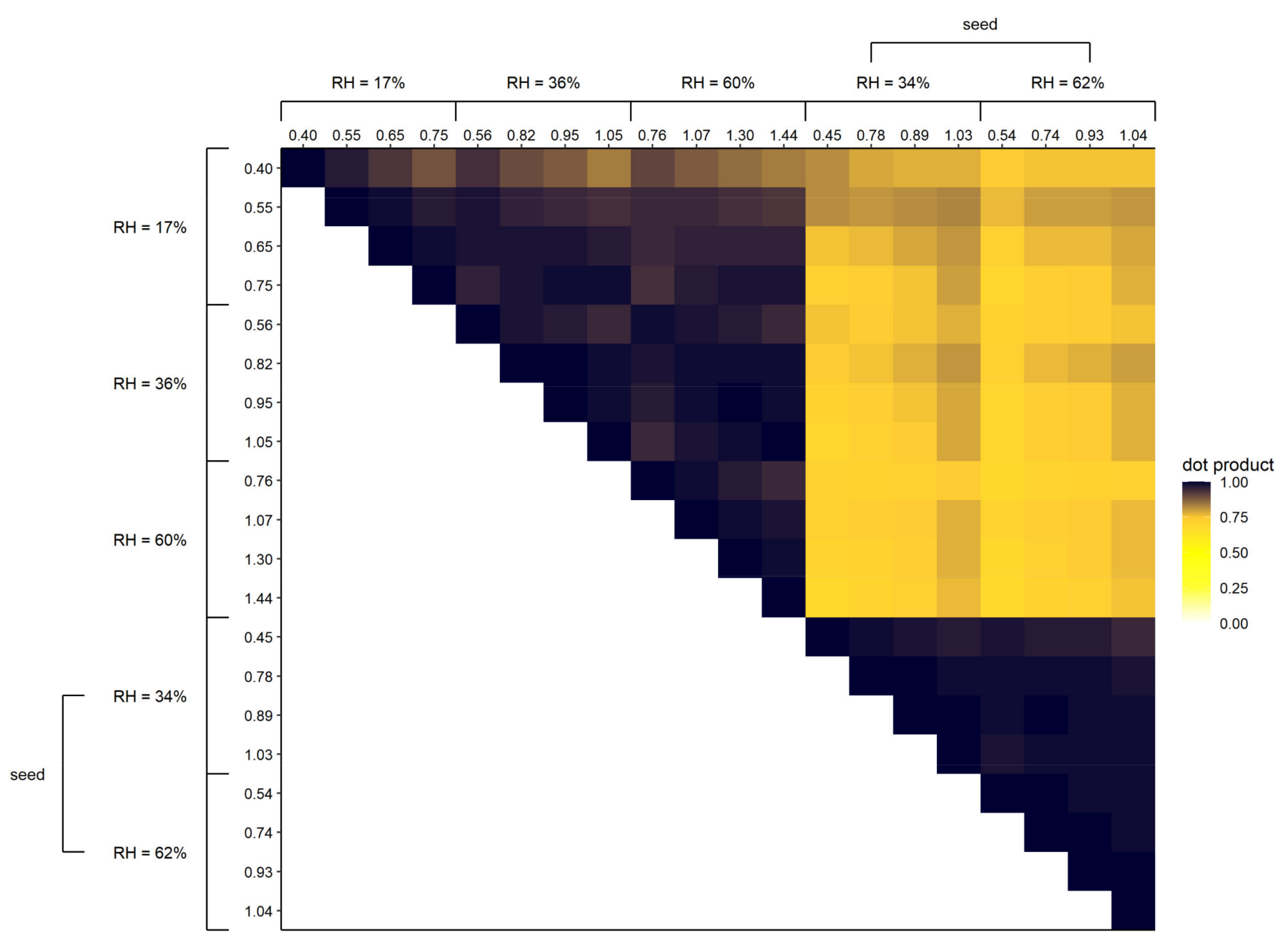

Figure 4. The dot products between mass spectrums obtained under different experimental conditions. Numbers on the $x-$ and $\mathrm{y}$-axis correspond to the $\mathrm{OH}$ exposure of that experiment in $10^{12} \mathrm{molec} \mathrm{cm}^{-3} \mathrm{~s}$. Numeric results were presented in Supporting Information Table S2.

\subsubsection{Effect of RH on the Chemical Composition of Gas Phase Products}

It has been reported in previous studies that $\mathrm{RH}$ will change the chemical composition of gas phase and particle phase oxidation products of different VOCs. The effect of RH on the chemical composition of gas phase products can again be examined by the dot products between experiments carried out at different RH as shown by Figure 4. In most of the cases, dot products between spectrums are larger than 0.9 with deep blue color, indicating great similarities between them. At the same time, it can be observed that dot products between $\mathrm{RH}=17 \%(0.4)$ and other RHs are smaller than all other dot products in experiments without using seed particles. This observation can be explained by the effect of $\mathrm{OH}$ exposure as presented in the previous section. Therefore, in general, the effect of $\mathrm{RH}$ on gas-phase product compositions in the current study is minimal. 


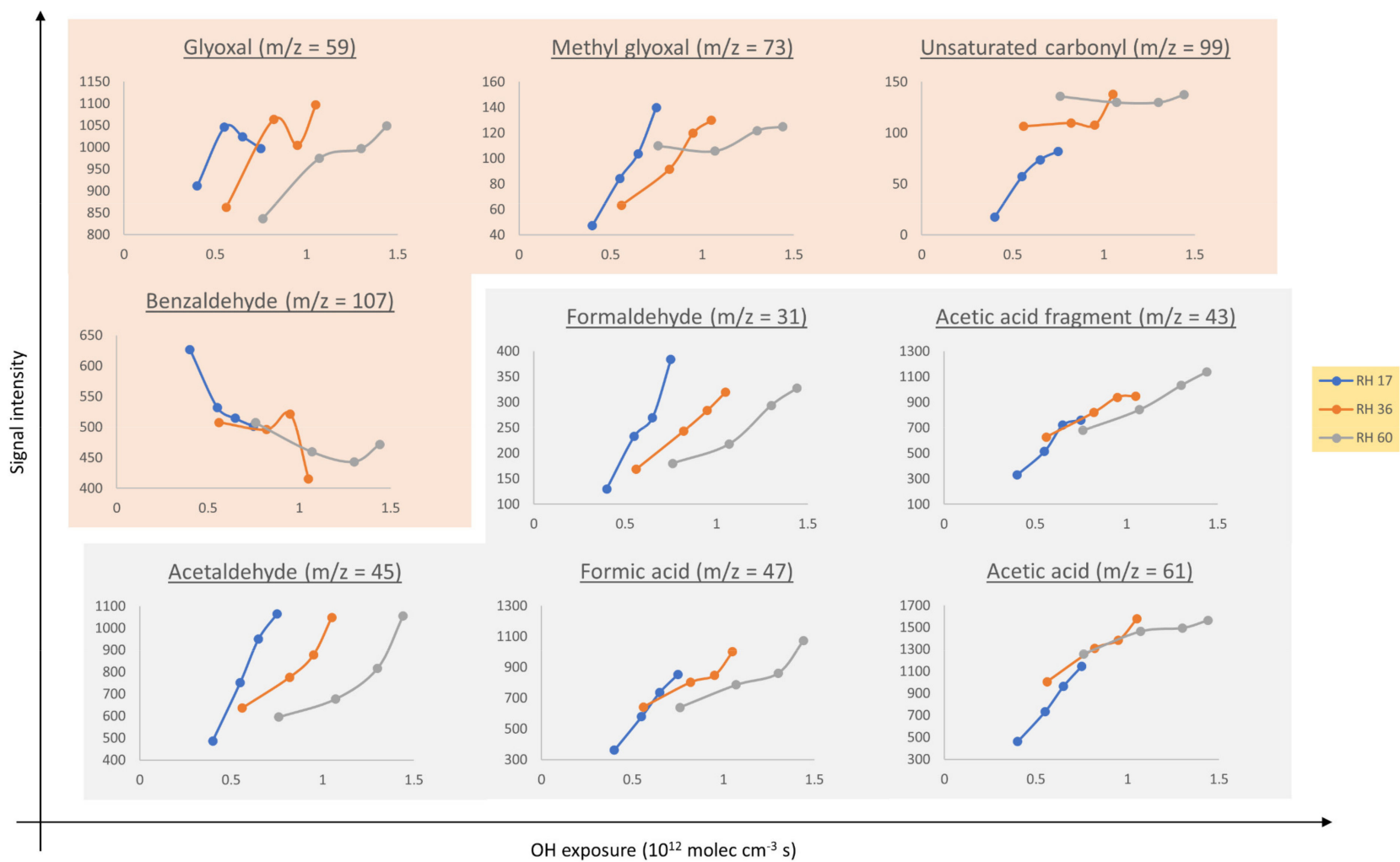

Figure 5. Changes in signal intensity of products observed by PTR-MS under different RH and OH exposure. Plots in light brown correspond to first generation products while plots in grey represents second generation products.

\subsubsection{Effect of $\left(\mathrm{NH}_{4}\right)_{2} \mathrm{SO}_{4}$ Seed}

To examine the effects of adding seed particles to the chemical composition of gas phase oxidation products, photooxidation experiments were repeated with the addition of $\left(\mathrm{NH}_{4}\right)_{2} \mathrm{SO}_{4}$ particle at $\mathrm{RH}=34 \%$ and $62 \%$. $\left(\mathrm{NH}_{4}\right)_{2} \mathrm{SO}_{4}$ was produced by passing $\left(\mathrm{NH}_{4}\right)_{2} \mathrm{SO}_{4}$ solution through an atomizer. The resulting wet stream of atomized $\left(\mathrm{NH}_{4}\right)_{2} \mathrm{SO}_{4}$ was then directed through a diffusion dryer and injected to the PAM OFR from an inlet other than the one for the main reactants. The initial mass concentration of $\left(\mathrm{NH}_{4}\right)_{2} \mathrm{SO}_{4}$ was around $78.4 \mu \mathrm{g} \mathrm{m}{ }^{-3}$.

Figure 6 depicted the spectrum obtained from experiments with seed particle. Compared with Figure 2, it is obvious that most of the peaks identified in seeded experiments were also present in experiments without seed particles. However, the weighing of peaks in Figure 6 is different from that in Figure 2. In particular, the dominating species in experiments without using seed particles are acetic acids and formic acids (as shown in Figure 2), while the most abundant peak in experiments with seed particle is glyoxal. This feature is also captured by the dot product calculation. Dot products between experiments with and without using the seed particle (area in light brown) are smaller dot products in other conditions. However, data obtained from the current study is insufficient to conclude the origin of the enhanced glyoxal level observed. 


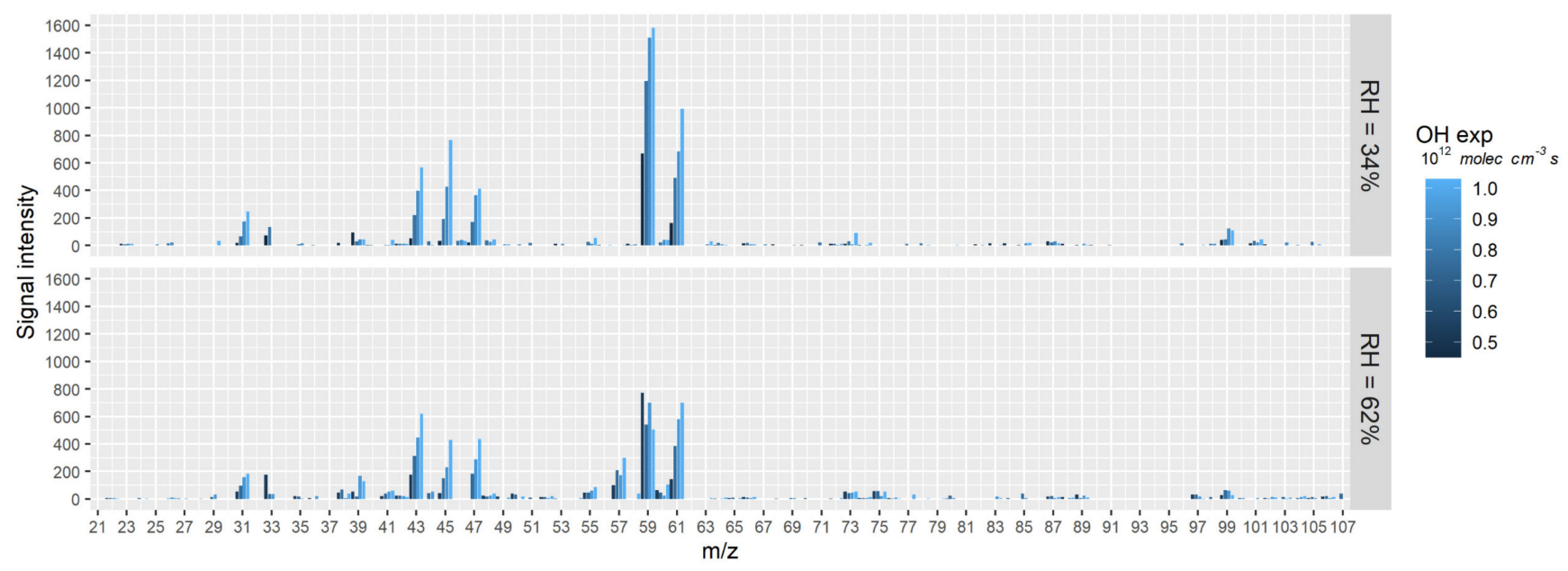

Figure 6. Mass spectrum of gas phase products observed in experiments using $\left(\mathrm{NH}_{4}\right)_{2} \mathrm{SO}_{4}$ seed particles. All the spectrums shown are background $(\mathrm{OH}$ exposure $=0)$ subtracted.

\subsection{Particle Phase Products}

\subsubsection{Number and Mass Concentration of SOA}

The effect of increasing $\mathrm{OH}$ exposure on the number and mass concentration of SOA in the absence of seed particle was depicted in Figure 7. The change of SOA mass and number concentration under different $\mathrm{OH}$ exposure was monitored by a SMPS. According to the user manual of SMPS [37], the mass concentration of a sample is calculated from the particle number concentration and diameter distribution of the sample with the assumption that the particle is spherical in shape with a certain density (set to $1 \mathrm{~g} \mathrm{~cm}^{-3}$ in this study). Figure 7 showed that SOA mass concentration increases with OH exposure, while SOA number concentration first increases and then decreases with increasing $\mathrm{OH}$ exposure. It has been shown in previous studies that at high $\mathrm{OH}$ exposure, chemical reaction changes from functionalization (addition of oxygen atom to the product) to fragmentation (breaking of carbon-carbon bond), causing a decrease in SOA mass yield [26]. In their study, the transition from functionalization to fragmentation take place at $\mathrm{OH}$ exposure around $0.5-1 \times 10^{12}$ molec $\mathrm{cm}^{-3} \mathrm{~s}$. The transition of reaction type in the aforementioned study may help to explain the observed decrease of particle number in the current study, which also occurs at $\mathrm{OH}$ exposure around $0.5-1 \times 10^{12} \mathrm{molec}^{-3} \mathrm{~s}$. However, it cannot explain the constant increase of SOA mass concentration at this range of $\mathrm{OH}$ exposure. The increase in SOA mass concentration indicates the formation of larger particles, since the particle density was assumed to be $1 \mathrm{~g} \mathrm{~cm}^{-3}$ in all experiments. One possible reason for the observed increase in particle mass concentration is the oligomerization of oxidation products. As shown by Loeffler et al. [38], glyoxal and methyl glyoxal can form dimer and trimers effectively. The combination of smaller particles to form a larger particle may help to explain the increase in particle mass concentration observed. However, results from the current study are insufficient to confirm the building blocks of the oligomers. Further studies are needed to identify the formation mechanism and composition of the possible oligomerization processes. 

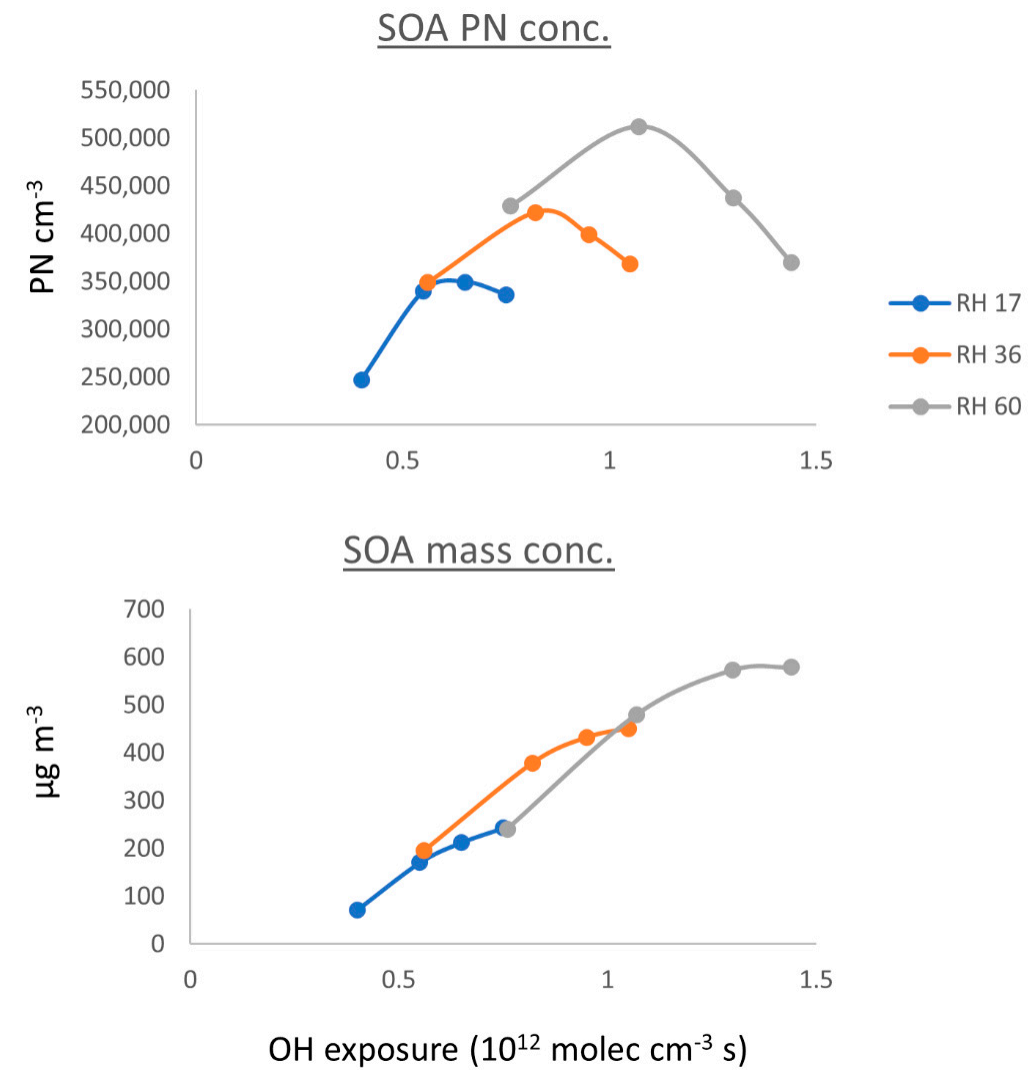

Figure 7. Changes of SOA particle number $(\mathrm{PN})$ concentration and mass concentration under different $\mathrm{RH}$ and $\mathrm{OH}$ exposure.

\subsubsection{Chemical Characterization of Particle Phase Products}

SOA samples collected in the current study were analyzed for its chemical composition by GC/MS. Chromatograms of the SOA sample are shown in Figure S2 in Supporting Information. The five most abundant organic acids identified in the sample were listed in Table 2. As shown in the table, four out of five acids are dicarboxylic acids, and the remaining one is the well-known toluene SOA tracer DHOPA. The first four acids in Table 2 have previously been identified in other studies. They are probably originated from the unsaturated carbonyl compound formed as the first generation product in gas phase. The proposed formation mechanism of these four acids were outlined in Figure 8.

Table 2. List of particle phase products identified in SOA sample.

2,3-Dihydroxy-4-
oxopentanoic acid
(DHOPA)


Table 2. Cont.

Molecular Weight $\begin{gathered}\text { Average Mass on } \\ \text { Each Filter (ng) }\end{gathered}$
$\begin{gathered}\text { Pato, Hatakeyama and } \\ \text { Imamura [42] }\end{gathered}$
Walic acid

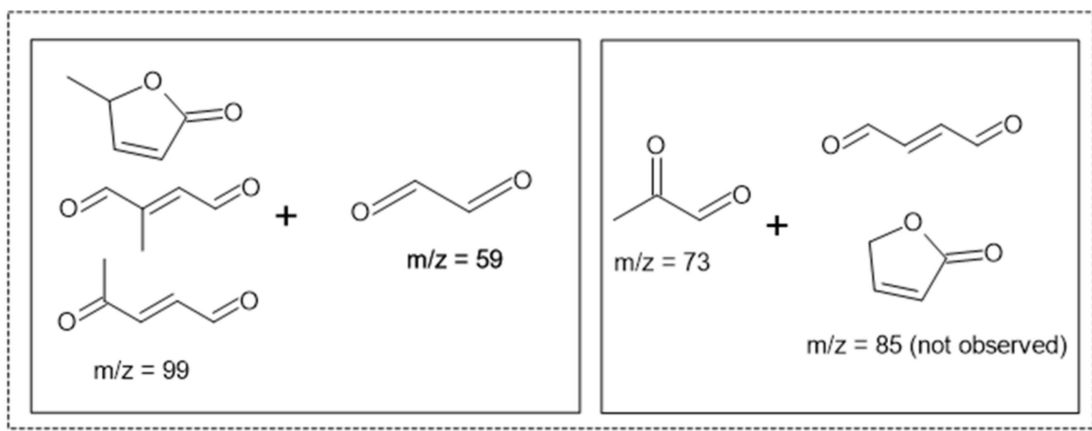<smiles>CC(C=O)=CC=O</smiles><smiles>CC(=O)/C=C/C=O</smiles><smiles>[Y][C@H](C)O</smiles><smiles>CC(O)(C=O)CC=O</smiles><smiles>[3H][14CH2]O</smiles><smiles>CC(O)(CC(=O)O)C(=O)O</smiles>

Citramalic acid<smiles>CC(=O)C(O)C(O)C=O</smiles><smiles>[3H][13CH3]</smiles><smiles>CC(=O)C(O)C(O)C(=O)O</smiles>

2,3-dihydroxy-4-oxoentanoic acid<smiles>C[14C](O)(O)C(O)C(O)C=O</smiles>

Malic acid

Figure 8. Proposed formation mechanism of particle phase products observed in the current study.

C5 diacids, such as glutaric acid, 3-hydroxyglutaric acid, and 2,3-dihydroxyglutaric acid, have been identified in many SOA samples, including SOA collected from urban and rural areas [40,41,44,45], as well as from cyclohexene oxidation [46,47]. However, to the best of our knowledge, the identification of $\mathrm{C} 5$ diacids has not been reported in SOA 
sample derived from toluene. 2,3-dihydroxyglutaric acid identified in the SOA sample of the current study is unlikely originated from the gas-particle partitioning of gas phase oxidation products, since in the PTR-MS result of the current study, as well as the MCM database, no compound that could lead to the formation of it can be found. Therefore, we suggest that it is either formed through particle phase reaction or the recombination of small fragmentation products. In any case, its formation mechanism under high $\mathrm{OH}$ condition warrants further investigation. Apart from glutaric acid, all other particle phase products identified in the current study agree with previous studies, again suggesting that the use of PAM OFR to study atmospherically relevant oxidation reaction is reliable.

\section{Conclusions}

The current study examined the reaction mechanism of the photooxidation and ageing of toluene using the PAM OFR. The range of $\mathrm{OH}$ exposure studied spanned from 0.4 to $1.5 \times 10^{12}$ molec $\mathrm{cm}^{-3} \mathrm{~s}$, which is equivalent to 3 to 12 days of atmospheric oxidation. Results showed that $\mathrm{OH}$ exposure has minimal effect on the gas phase products formed, while an increase in $\mathrm{OH}$ exposure will increase the yield of second generation gas phase products. The composition of gas phase product obtained under different $\mathrm{RH}$ are similar, except for the experiment conducted at $\mathrm{RH}=17 \%$ and $\mathrm{OH}$ exposure $=0.4 \times 10^{12} \mathrm{molec}$ $\mathrm{cm}^{-3} \mathrm{~s}$. Experiments using $\left(\mathrm{NH}_{4}\right)_{2} \mathrm{SO}_{4}$ seed particle showed similar gas phase products composition, but the spectrum is dominated by glyoxal $(m / z=59)$. The mass concentration of SOA increased with increasing $\mathrm{OH}$ exposure, while the PN concentration of SOA first increased then decreased with increasing $\mathrm{OH}$ exposure. It was also found that the SOA samples in the current study were dominated by highly oxygenated dicarboxylic acids. In general, the results of the current study showed good agreement with previous studies carried out in smog chambers. It shows that using PAM OFR to study the reaction mechanism of photooxidation and ageing of different VOCs in the atmosphere is reliable, and, with stringent control in experimental conditions, atmospherically relevant.

Supplementary Materials: The following are available online at https:/ /www.mdpi.com/article/10 .3390/atmos12070915/s1, Figure S1: Calibration curve of OH exposure under different RH, Table S1: Experiment list for gas phase product study, Figure S2: Total ion chromatogram of aerosol samples and target compounds. Target Compounds: \#1, Citramalic acid; \#2, 2,3-Dihydroxy-4-oxopentanoic acid; \#3, Malic acid; \#4, Tataric acid; \#5, 2,3-dihydroxy-glutraric acid, Table S2: Dot products between spectrums obtained in each experiment. The unit of OH exposure is $1 \times 1012 \mathrm{molec} \mathrm{cm}^{-3} \mathrm{~s}$. Areas in grey represent dot products between experiments of different $\mathrm{RH}$, and areas in light brown represent dot products between experiments with and without using seed particles.

Author Contributions: Conceptualization, Y.-S.L. and K.-F.H.; Data curation, Y.-S.L.; Formal analysis, Y.-S.L.; Funding acquisition, K.-F.H.; Investigation, Y.-S.L., M.-N.C., H.-Y.P., Y.T. and J.L.; Methodology, Y.-S.L. and K.-F.H.; Project administration, K.-F.H.; Resources, M.-N.C., Y.T., S.-C.L. and K.-F.H.; Software, Y.-S.L. and Y.T.; Supervision, M.-N.C., S.-C.L., J.L. and K.-F.H.; Validation, Y.-S.L., H.-Y.P. and K.-F.H.; Visualization, Y.-S.L.; Writing-original draft, Y.-S.L., H.-Y.P. and K.-F.H.; Writingreview \& editing, Y.-S.L., J.L. and K.-F.H. All authors have read and agreed to the published version of the manuscript.

Funding: This study was supported by grants from the Research Grant Council of the Hong Kong Special Administrative Region China, Theme-Based Research Scheme (T24-504/17-N) and General Research Fund (Project No. CUHK 14205318).

Institutional Review Board Statement: Not applicable.

Informed Consent Statement: Not applicable.

Data Availability Statement: Data are available upon request to the authors.

Conflicts of Interest: The authors declare no conflict of interest. 


\section{References}

1. Huang, R.-J.; Zhang, Y.; Bozzetti, C.; Ho, K.-F.; Cao, J.-J.; Han, Y.; Daellenbach, K.R.; Slowik, J.G.; Platt, S.M.; Canonaco, F.; et al. High secondary aerosol contribution to particulate pollution during haze events in China. Nature 2014, 514, 218-222. [CrossRef] [PubMed]

2. Shrivastava, M.; Cappa, C.D.; Fan, J.; Goldstein, A.H.; Guenther, A.B.; Jimenez, J.L.; Kuang, C.; Laskin, A.; Martin, S.T.; Ng, N.L.; et al. Recent advances in understanding secondary organic aerosol: Implications for global climate forcing. Rev. Geophys. 2017, 55, 509-559. [CrossRef]

3. Hallquist, M.; Wenger, J.C.; Baltensperger, U.; Rudich, Y.; Simpson, D.; Claeys, M.; Dommen, J.; Donahue, N.M.; George, C.; Goldstein, A.H.; et al. The formation, properties and impact of secondary organic aerosol: Current and emerging issues. Atmos. Chem. Phys. 2009, 9, 5155-5236. [CrossRef]

4. Tuet, W.Y.; Chen, Y.; Fok, S.; Champion, J.A.; Ng, N.L. Inflammatory responses to secondary organic aerosols (SOA) generated from biogenic and anthropogenic precursors. Atmos. Chem. Phys. 2017, 17, 11418-11440. [CrossRef]

5. Ng, N.L.; Canagaratna, M.R.; Zhang, Q.; Jimenez, J.L.; Tian, J.; Ulbrich, I.M.; Kroll, J.H.; Docherty, K.S.; Chhabra, P.S.; Bahreini, R.; et al. Organic aerosol components observed in Northern Hemispheric datasets from Aerosol Mass Spectrometry. Atmos. Chem. Phys. 2010, 10, 4610-4641. [CrossRef]

6. Davidson, C.I.; Phalen, R.F.; Solomon, P.A. Airborne Particulate Matter and Human Health: A Review. Aerosol Sci. Technol. 2005, 39, 737-749. [CrossRef]

7. Valavanidis, A.; Fiotakis, K.; Vlachogianni, T. Airborne particulate matter and human health: Toxicological assessment and importance of size and composition of particles for oxidative damage and carcinogenic mechanisms. J. Environ. Sci. Health C 2008, 26, 339-362. [CrossRef]

8. Ng, N.L.; Brown, S.S.; Archibald, A.T.; Atlas, E.; Cohen, R.C.; Crowley, J.N.; Day, D.A.; Donahue, N.M.; Fry, J.L.; Fuchs, H.; et al. Nitrate radicals and biogenic volatile organic compounds: Oxidation, mechanisms, and organic aerosol. Atmos. Chem. Phys. 2017, 17, 2103-2162. [CrossRef]

9. Kroll, J.H.; Seinfeld, J.H. Chemistry of secondary organic aerosol: Formation and evolution of low-volatility organics in the atmosphere. Atmos. Environ. 2008, 42, 3593-3624. [CrossRef]

10. Ziemann, P.J.; Atkinson, A.R. Kinetics, products, and mechanisms of secondary organic aerosol formation. Chem. Soc. Rev. 2012, 41, 6582-6605. [CrossRef]

11. Rollins, A.W.; Pusede, S.; Wooldridge, P.; Min, K.E.; Gentner, D.R.; Goldstein, A.H.; Liu, S.; Day, D.A.; Russell, L.M.; Rubitschun, C.L.; et al. Gas/particle partitioning of total alkyl nitrates observed with TD-LIF in Bakersfield. J. Geophys. Res. Atmos. 2013, 118, 6651-6662. [CrossRef]

12. Deng, W.; Liu, T.; Zhang, Y.; Situ, S.; Hu, Q.; He, Q.; Zhang, Z.; Lü, S.; Bi, X.; Wang, X.; et al. Secondary organic aerosol formation from photo-oxidation of toluene with $\mathrm{NOx}$ and $\mathrm{SO}_{2}$ : Chamber simulation with purified air versus urban ambient air as matrix. Atmos. Environ. 2017, 150, 67-76. [CrossRef]

13. Robinson, A.L.; Donahue, N.M.; Shrivastava, M.K.; Weitkamp, E.A.; Sage, A.M.; Grieshop, A.P.; Lane, T.E.; Pierce, J.R.; Pandis, S.N. Rethinking Organic Aerosols: Semivolatile Emissions and Photochemical Aging. Science 2007, 315, 1259. [CrossRef]

14. Liggio, J.; Li, S.-M.; Hayden, K.; Taha, Y.M.; Stroud, C.; Darlington, A.; Drollette, B.D.; Gordon, M.; Lee, P.; Liu, P.; et al. Oil sands operations as a large source of secondary organic aerosols. Nature 2016, 534, 91-94. [CrossRef]

15. Lu, Q.; Murphy, B.N.; Qin, M.; Adams, P.J.; Zhao, Y.; Pye, H.O.T.; Efstathiou, C.; Allen, C.; Robinson, A.L. Simulation of organic aerosol formation during the CalNex study: Updated mobile emissions and secondary organic aerosol parameterization for intermediate-volatility organic compounds. Atmos. Chem. Phys. 2020, 20, 4313-4332. [CrossRef]

16. Peng, Z.; Jimenez, J.L. Radical chemistry in oxidation flow reactors for atmospheric chemistry research. Chem. Soc. Rev. 2020, 49, 2570-2616. [CrossRef]

17. Kang, E.; Root, M.J.; Toohey, D.W.; Brune, W.H. Introducing the concept of Potential Aerosol Mass (PAM). Atmos. Chem. Phys. 2007, 7, 5727-5744. [CrossRef]

18. Tkacik, D.S.; Lambe, A.T.; Jathar, S.; Li, X.; Presto, A.A.; Zhao, Y.; Blake, D.; Meinardi, S.; Jayne, J.T.; Croteau, P.L.; et al. Secondary organic aerosol formation from in-use motor vehicle emissions using a potential aerosol mass reactor. Environ. Sci. Technol. 2014, 48, 11235-11242. [CrossRef]

19. Zhao, Y.; Lambe, A.T.; Saleh, R.; Saliba, G.; Robinson, A.L. Secondary Organic Aerosol Production from Gasoline Vehicle Exhaust: Effects of Engine Technology, Cold Start, and Emission Certification Standard. Environ. Sci. Technol. 2018, 52, $1253-1261$. [CrossRef]

20. Lambe, A.T.; Onasch, T.B.; Massoli, P.; Croasdale, D.R.; Wright, J.P.; Ahern, A.T.; Williams, L.R.; Worsnop, D.R.; Brune, W.H.; Davidovits, P. Laboratory studies of the chemical composition and cloud condensation nuclei (CCN) activity of secondary organic aerosol (SOA) and oxidized primary organic aerosol (OPOA). Atmos. Chem. Phys. 2011, 11, 8913-8928. [CrossRef]

21. Molteni, U.; Bianchi, F.; Klein, F.; el Haddad, I.; Frege, C.; Rossi, M.J.; Dommen, J.; Baltensperger, U. Formation of highly oxygenated organic molecules from aromatic compounds. Atmos. Chem. Phys. 2018, 18, 1909-1921. [CrossRef]

22. Palm, B.B.; Campuzano-Jost, P.; Day, D.A.; Ortega, A.M.; Fry, J.L.; Brown, S.S.; Zarzana, K.J.; Dube, W.; Wagner, N.L.; Draper, D.C.; et al. Secondary organic aerosol formation from in situ $\mathrm{OH}, \mathrm{O}_{3}$, and $\mathrm{NO}_{3}$ oxidation of ambient forest air in an oxidation flow reactor. Atmos. Chem. Phys. 2017, 17, 5331-5354. [CrossRef] 
23. Ma, J.; Chu, B.; Liu, J.; Liu, Y.; Zhang, H.; He, H. NOx promotion of SO2 conversion to sulfate: An important mechanism for the occurrence of heavy haze during winter in Beijing. Environ. Pollut. 2018, 233, 662-669. [CrossRef] [PubMed]

24. Lambe, A.T.; Chhabra, P.S.; Onasch, T.B.; Brune, W.H.; Hunter, J.F.; Kroll, J.H.; Cummings, M.J.; Brogan, J.F.; Parmar, Y.; Worsnop, D.R.; et al. Effect of oxidant concentration, exposure time, and seed particles on secondary organic aerosol chemical composition and yield. Atmos. Chem. Phys. 2015, 15, 3063-3075. [CrossRef]

25. Ortega, A.M.; Day, D.A.; Cubison, M.J.; Brune, W.H.; Bon, D.; de Gouw, J.A.; Jimenez, J.L. Secondary organic aerosol formation and primary organic aerosol oxidation from biomass-burning smoke in a flow reactor during FLAME-3. Atmos. Chem. Phys. 2013, 13, 11551-11571. [CrossRef]

26. Lambe, A.T.; Onasch, T.B.; Croasdale, D.R.; Wright, J.P.; Martin, A.T.; Franklin, J.P.; Massoli, P.; Kroll, J.H.; Canagaratna, M.R.; Brune, W.H.; et al. Transitions from functionalization to fragmentation reactions of laboratory secondary organic aerosol (SOA) generated from the $\mathrm{OH}$ oxidation of alkane precursors. Environ. Sci. Technol. 2012, 46, 5430-5437. [CrossRef]

27. Wang, Y.; Mehra, A.; Krechmer, J.E.; Yang, G.; Hu, X.; Lu, Y.; Lambe, A.; Canagaratna, M.; Chen, J.; Worsnop, D.; et al. Oxygenated products formed from $\mathrm{OH}$-initiated reactions of trimethylbenzene: Autoxidation and accretion. Atmos. Chem. Phys. 2020, 20, 9563-9579. [CrossRef]

28. Lambe, A.T.; Ahern, A.T.; Williams, L.R.; Slowik, J.G.; Wong, J.P.S.; Abbatt, J.P.D.; Brune, W.H.; Ng, N.L.; Wright, J.P.; Croasdale, D.R.; et al. Characterization of aerosol photooxidation flow reactors: Heterogeneous oxidation, secondary organic aerosol formation and cloud condensation nuclei activity measurements. Atmos. Meas. Tech. 2011, 4, 445-461. [CrossRef]

29. Rattigan, O.V.; Boniface, J.; Swartz, E.; Davidovits, P.; Jayne, J.T.; Kolb, C.E.; Worsnop, D.R. Uptake of gas-phase $\mathrm{SO}_{2}$ in aqueous sulfuric acid: Oxidation by $\mathrm{H}_{2} \mathrm{O}_{2}, \mathrm{O}_{3}$, and HONO. J. Geophys. Res. Atoms. 2000, 105, 29065-29078. [CrossRef]

30. Mao, J.; Ren, X.; Brune, W.H.; Olson, J.R.; Crawford, J.H.; Fried, A.; Huey, L.G.; Cohen, R.C.; Heikes, B.; Singh, H.B.; et al. Airborne measurement of $\mathrm{OH}$ reactivity during INTEX-B. Atmos. Chem. Phys. 2009, 9, 163-173. [CrossRef]

31. Johnson, D.; Jenkin, M.E.; Wirtz, K.; Martin-Reviejo, M. Simulating the Formation of Secondary Organic Aerosol from the Photooxidation of Toluene. Environ. Chem. 2004, 1, 150-165. [CrossRef]

32. Maleknia, S.D.; Bell, T.L.; Adams, M.A. PTR-MS analysis of reference and plant-emitted volatile organic compounds. Int. J. Mass. Spectrom. 2007, 262, 203-210. [CrossRef]

33. Calvert, J.G.; Atkinson, R.; Becker, K.H.; Kamens, R.M.; Seinfeld, J.H.; Wallington, T.H.; Yarwood, G. The Mechanisms of Atmospheric Oxidation of the Aromatic Hydrocarbons; Oxford University Press: Oxford, UK, 2002.

34. Ji, Y.; Zhao, J.; Terazono, H.; Misawa, K.; Levitt, N.P.; Li, Y.; Lin, Y.; Peng, J.; Wang, Y.; Duan, L.; et al. Reassessing the atmospheric oxidation mechanism of toluene. Proc. Natl. Acad. Sci. USA 2017, 114, 8169-8174. [CrossRef]

35. Arey, J.; Obermeyer, G.; Aschmann, S.M.; Chattopadhyay, S.; Cusick, R.D.; Atkinson, R. Dicarbonyl Products of the OH Radical-Initiated Reaction of a Series of Aromatic Hydrocarbons. Environ. Sci. Technol. 2009, 43, 683-689. [CrossRef] [PubMed]

36. Marcolli, C.; Canagaratna, M.R.; Worsnop, D.R.; Bahreini, R.; de Gouw, J.A.; Warneke, C.; Goldan, P.D.; Kuster, W.C.; Williams, E.J.; Lerner, B.M.; et al. Cluster Analysis of the Organic Peaks in Bulk Mass Spectra Obtained During the 2002 New England Air Quality Study with an Aerodyne Aerosol Mass Spectrometer. Atmos. Chem. Phys. 2006, 6, 5649-5666. [CrossRef]

37. TSI. Aerosol Instrument Manager Sofware for Scanning Mobility Particle Sizer (SMPS) Spectrometer, User's Manual; TSI: Shoreview, MN, USA, 2010.

38. Loeffler, K.W.; Koehler, C.A.; Paul, N.M.; de Haan, D.O. Oligomer Formation in Evaporating Aqueous Glyoxal and Methyl Glyoxal Solutions. Environ. Sci. Technol. 2006, 40, 6318-6323. [CrossRef]

39. Kleindienst, T.E.; Conver, T.S.; McIver, C.D.; Edney, E.O. Determination of secondary organic aerosol products from the photooxidation of toluene and their implications in ambient PM2.5. J. Atmos. Chem. 2004, 47, 79-100. [CrossRef]

40. Lewandowski, M.; Jaoui, M.; Kleindienst, T.E.; Offenberg, J.H.; Edney, E.O. Composition of PM2.5 during the summer of 2003 in Research Triangle Park, North Carolina. Atmos. Environ. 2007, 41, 4073-4083. [CrossRef]

41. Hu, D.; Bian, Q.; Li, T.W.Y.; Lau, A.K.H.; Yu, J.Z. Contributions of isoprene, monoterpenes, $\beta$-caryophyllene, and toluene to secondary organic aerosols in Hong Kong during the summer of 2006. J. Geophys. Res. Atmos. 2008, 113. [CrossRef]

42. Sato, K.; Hatakeyama, S.; Imamura, T. Secondary organic aerosol formation during the photooxidation of toluene: NOx dependence of chemical composition. J. Phys. Chem. A 2007, 111, 9796-9808. [CrossRef]

43. White, S.J.; Jamie, I.M.; Angove, D.E. Chemical characterisation of semi-volatile and aerosol compounds from the photooxidation of toluene and NOx. Atmos. Environ. 2014, 83, 237-244. [CrossRef]

44. Ding, X.; Wang, X.-M.; Zheng, M. The influence of temperature and aerosol acidity on biogenic secondary organic aerosol tracers: Observations at a rural site in the central Pearl River Delta region, South China. Atmos. Environ. 2011, 45, 1303-1311. [CrossRef]

45. Claeys, M.; Graham, B.; Vas, G.; Wang, W.; Vermeylen, R.; Pashynska, V.; Cafmeyer, J.; Guyon, P.; Andreae, M.O.; Artaxo, P.; et al. Formation of Secondary Organic Aerosols Through Photooxidation of Isoprene. Science 2004, 303, 1173. [CrossRef] [PubMed]

46. Hamilton, J.F.; Lewis, A.C.; Reynolds, J.C.; Carpenter, L.J.; Lubben, A. Investigating the composition of organic aerosol resulting from cyclohexene ozonolysis: Low molecular weight and heterogeneous reaction products. Atmos. Chem. Phys. 2006, 6, 4973-4984. [CrossRef]

47. Liu, S.; Tsona, N.T.; Zhang, Q.; Jia, L.; Xu, Y.; Du, L. Influence of relative humidity on cyclohexene SOA formation from OH photooxidation. Chemosphere 2019, 231, 478-486. [CrossRef] [PubMed] 